\title{
Impact Of Deployment Of Personnel With Chronic Conditions To Forward Areas
}

\author{
TJ Hodgetts, LA Greasley
}

\begin{abstract}
Aim. To identify reasons for inappropriate deployment of soldiers with chronic conditions to an operational environment.
\end{abstract}

Setting. Two British Army field hospitals in Kuwait, 08 February to 17 March 2003, during the period of troop concentration prior to war-fighting (Operation Telic).

Population. All British military personnel on land during the concentration phase, rising to an estimated 28,000 troops.

Methods. Real-time electronic record maintained of all cases presenting to 22 and 33 Field Hospitals judged to be inappropriately deployed.

Results. 50 sequential cases were analysed. $34 \%$ were downgraded prior to deployment. Of those who were P2 FE, $85 \%$ were judged to have required protection from deployment by downgrading. $20 \%$ of all cases had a history of chronic asthma, and of the asthmatics $60 \%(6 / 10)$ were not downgraded. $18 \%$ of all cases were deployed while waiting for secondary care investigation or review that should have ensured protection from deployment. No patient had an existing "FT" (forward temperate) or "LT" (lines of communication temperate) grading: but in four cases it was predictable that the patient's underlying condition would be adversely affected by deployment to a desert environment. In 5 cases it was identified that the inappropriate deployment could be attributed to clinical management within the civilian sector, with a consequent failure to institute the necessary downgrading process.

Conclusions. Review of the medical grading process is needed to protect those soldiers who are awaiting outpatient opinion or definitive diagnosis from investigation, and to provide an employability grading that matches a soldier's fitness for operational role.

\section{Background}

The subjective experience of Emergency Medicine deployed at Role 3 since OP AGRICOLA 1999 is for a recognisable trend of personnel with chronic conditions who are deployed inappropriately into the field environment. These personnel character- istically present to secondary care (Role 3) soon after deployment and are invariably removed from Theatre. This will likely result in frustration for both the individual (who may have deployed reluctantly, or with false expectations of the support available in the field) and the commander (who will be deprived of manpower that will be difficult to replace at short notice).

This paper analyses 50 consecutive cases of "inappropriate deployment" on OP TELIC, during the phase of preparation for war. Recommendations are made to avoid inappropriate deployments in the future.

\section{Setting}

Data was collected at 22 Field Hospital and 33 Field Hospital during Operation TELIC. 22 Field Hospital deployed on 08 February 2003 to establish a 25-bed Role 3 facility in support of British Forces concentrating in tented camps in Kuwait prior to warfighting. 33 Field Hospital declared fully operationally capable (FOC) at 200-beds on the same site in Northern Kuwait on 06 March 2003, with a transfer of clinical staff and capability from 22 Field Hospital. 33 Field Hospital handed over the facility to staff of 202 Field Hospital on 17 March 2003.

All personnel deployed on Operation TELIC required the physical capacity to tolerate NBC Dress State 4 Romeo (wearing full protective clothing and respirator), and had to be able to run to anti-SCUD defences (slit trenches) to protect themselves. The environment was open desert in Spring, with a predictable steady rise in daytime temperatures.

\section{Population}

The population served by 22 and 33 Field Hospitals was all British Forces on land in Kuwait. British Forces afloat in the Persian Gulf received Role 3 support from RFA Argus. Available figures for the population at risk were 9100 on 15 February 2003, rising to 28,000 on 10 March 2003.

\section{Methods}

An electronic record was maintained of all cases that presented to the A\&E Department of 22 and 33 Field Hospitals who had chronic conditions at the time of deployment, and who were seeking support for their known chronic condition. This included cases who self-referred or who were referred by their Regimental Medical Officer. Cases who were 
referred direct to a specialty may have been missed, although the close working environment of the 25-bed field hospital (and specifically a sole junior doctor shared by $\mathrm{A} \& \mathrm{E}$ and the wards) made this unlikely. Cases that were managed administratively at Role 1 and removed from Theatre without referral to the Role 3 hospital may potentially have been missed, but liaison with Brigade Support Group was used to ensure their identification. Cases that presented to other deployed Role 3 units (202 Field Hospital, 34 Field Hospital, and RFA Argus), or to Role 1 land units outside this study period, have not been captured.

It is recognised that the study is not comprehensive, but represents a snapshot of the system failures that allow the inappropriate deployment of soldiers with chronic conditions.

\section{Results}

50 personnel were identified as "inappropriate" operational deployments with chronic medical conditions in the period 08 February 2003 to 17 March 2003.

Table 1 lists the clinical conditions by system. Table 2 lists the details of each case and their disposal in chronological order of presentation.

$17(34 \%)$ were downgraded prior to deployment, and of these 16 were P3 LE and 1 was P7 HO. Of those whose grade was P2 FE, 85\% (28/33) arguably should have been downgraded.

$20 \%$ of all patients $(10 / 50)$ had a history of chronic asthma, and of these $60 \%(6 / 10)$ were not downgraded.

$18 \%$ of cases $(9 / 50)$ were deployed while waiting for secondary care investigation or review that should have ensured protection from deployment. There were examples of patients cancelling their own appointment

Table 1. Clinical condition by system. (serial 10) or being denied access to secondary care review by their seniors (serial 26).

No patient had an existing "FT" (forward temperate) or "LT" (lines of communication temperate) grading. In four cases it was predictable that the patient's underlying condition would be adversely affected by deployment to a desert environment (serials $3,7,16$ and 38).

In 5 cases it was identified that the inappropriate deployment could be attributed to clinical management within the civilian sector, with a consequent failure to institute the necessary downgrading process (serials $22,29,34,40$ and 45).

Two patients were deployed wearing a plaster of Paris cast, who were neither able to perform their duties or wear full IPE (serials $9 \& 30)$.

In 2 instances there was a failure of the patient's supervising clinician prior to deployment to appreciate the limitations of a Field Hospital, with respect to available laboratory investigations (serial 2) and the deployed clinical capability (serial 45). In 2 further instances patients were deployed requiring repeat prescription of drugs that are not part of the deployable medical module contents (serials 4 and 5).

One case could be classified as having been deployed with their existing downgrading ignored (case 33). 25 cases could be classified as holding an inappropriate medical grade for their known condition, thereby not being protected from deployment (cases 1-3, 7,8, $11,14-19,21,25,26,28,32,37-39,41,43$, $46,47,49)$.

11 cases represented poor medical judgement, where the patient was knowingly allowed to deploy with an untreated or partially treated condition that would require Role 3 care in Theatre of Operation (cases 6, 9, 22-24, 29-31, 42, 44, 48).

\begin{tabular}{|c|c|c|}
\hline System & Number of cases & Comment \\
\hline $\begin{array}{l}\text { Orthopaedics and } \\
\text { Rheumatology }\end{array}$ & 13 & \\
\hline Respiratory & 11 & 10 were chronic asthma \\
\hline Gastrointestinal & 4 & \\
\hline Renal and Urology & 4 & \\
\hline Endocrine & 3 & \\
\hline General surgery & 3 & \\
\hline Gynaecology & 2 & \\
\hline Psychiatry & 2 & \\
\hline Immunology & 2 & \\
\hline Ear, nose \& throat & 2 & \\
\hline Dermatology & 1 & \\
\hline Maxillofacial & 1 & \\
\hline Cardiology & 1 & \\
\hline Not recorded & 1 & $\begin{array}{l}\text { Administrative return to UK } \\
\text { from unit for soldier deployed } \\
\text { when P7 HO }\end{array}$ \\
\hline
\end{tabular}


Table 2. Case details and disposal in order of presentation.

\begin{tabular}{|c|c|c|c|}
\hline Serial & Clinical condition & $\begin{array}{l}\text { Deployed } \\
\text { Medical Grade }\end{array}$ & Actions and comments \\
\hline 1 & $\begin{array}{l}\text { Hypothyroidism taking thyroxine. } \\
\text { Presented with increasing weakness, } \\
\text { tiredness, hoarse voice and brittle hair. } \\
\text { Bradycardic, hypotensive and } \\
\text { hypothermic. }\end{array}$ & P3 LE & $\begin{array}{l}\text { No endocrine investigation } \\
\text { available. } \\
\text { AEROMED to UK. }\end{array}$ \\
\hline 2 & $\begin{array}{l}\text { Hepatitis presumed secondary to } 1 \text {-year } \\
\text { of minocycline therapy. Given blood } \\
\text { form by military doctor at Royal Hospital } \\
\text { Haslar for LFTs to be repeated in the } \\
\text { field. }\end{array}$ & P2 FE & $\begin{array}{l}\text { LFTs still abnormal. No clear } \\
\text { diagnosis of cause of hepatitis; at } \\
\text { risk if asked to take BATS (if } \\
\text { includes a tetracycline). Should } \\
\text { have been downgraded. } \\
\text { AEROMED to UK. }\end{array}$ \\
\hline 3 & $\begin{array}{l}\text { Acne conglobata taking isotretinoin } \\
\text { (contraindication: strong sunlight). } \\
\text { Referred for repeat LFTs and serum } \\
\text { lipids. Complaining of burning skin } \\
\text { and perioral dryness. }\end{array}$ & P2 FE & $\begin{array}{l}\text { This therapy is incompatible with a } \\
\text { desert deployment. Should have been } \\
\text { downgraded. Options were to stop } \\
\text { therapy and remain in theatre (with } \\
\text { an exacerbation of severe acne) or } \\
\text { return to unit in Germany. Returned } \\
\text { to Germany. Lipids are not available } \\
\text { in field laboratory. }\end{array}$ \\
\hline 4 & $\begin{array}{l}\text { Osteoarthritis of the knee requesting } \\
\text { resupply of amitryptilene, } \\
\text { indomethacin, and ranitidine. }\end{array}$ & P3 LE & $\begin{array}{l}\text { None of these drugs are in the deployed } \\
\text { scales. In theatre } 2 \text { weeks. Requirement } \\
\text { is to deploy with } 6 \text { months supply of } \\
\text { drugs. Soldier returned to duty until lack } \\
\text { of analgesia impacts on his ability to } \\
\text { perform duties (driver). Decision to } \\
\text { deploy is questionable. }\end{array}$ \\
\hline 5 & $\begin{array}{l}\text { Chronic gastro-oesophageal reflux } \\
\text { disease taking rabeprazole. } \\
\text { Requesting repeat prescription. }\end{array}$ & P3 LE & $\begin{array}{l}\text { This drug not in deployed scale. In } \\
\text { theatre less than } 2 \text { weeks. Requirement is } \\
\text { to deploy with } 6 \text { months supply of drugs. } \\
\text { Soldier returned to duty until symptoms } \\
\text { impact on his ability to perform duties. } \\
\text { Drug ordered as single line item. } \\
\text { Decision to deploy is questionable. }\end{array}$ \\
\hline 6 & $\begin{array}{l}\text { Bartholin's abscess given } 3 \text { courses } \\
\text { of antibiotics in UK. Patient told } \\
\text { required incision and drainage } \\
\text { prior to deployment. }\end{array}$ & P2 FE & $\begin{array}{l}\text { Allowed to deploy without correct } \\
\text { treatment undertaken. Admitted for } \\
\text { emergency procedure on arrival in } \\
\text { theatre. }\end{array}$ \\
\hline 7 & $\begin{array}{l}\text { History of recurrent ureteric calculi } \\
\text { x3 per year AND chronic prostatitis } \\
\text { requiring continuous antibiotics for } \\
4 \text { months. }\end{array}$ & P3 LE & $\begin{array}{l}\text { Should not have been deployed to this } \\
\text { environment. } \\
\text { AEROMED to UK. }\end{array}$ \\
\hline 8 & $\begin{array}{l}\text { Recurrent epistaxis during exercise for } \\
10 \text { years. No treatment given. Episodes } \\
\text { of epistaxis daily. No ENT capability } \\
\text { in theatre. }\end{array}$ & P2 FE & $\begin{array}{l}\text { Inadequate management prior to } \\
\text { deployment, with lack of perception of } \\
\text { limitations of deployed capability. }\end{array}$ \\
\hline 9 & $\begin{array}{l}\text { Plaster of Paris cast for fracture scaphoid, } \\
\text { unable to lift Bergen. }\end{array}$ & P2 FE & $\begin{array}{l}\text { No follow-up for } 7 \text { weeks after cast } \\
\text { applied. No downgrading. Inappropriate } \\
\text { posting. Repeat X-ray showed malunion } \\
\text { of fracture. AEROMED to UK. }\end{array}$ \\
\hline 10 & $\begin{array}{l}\text { Chef. } 4 \text { months of bloody diarrhoea. } \\
\text { Cancelled his own appointment at } \\
\text { MDHU Frimley before deploying. }\end{array}$ & P3 LE & $\begin{array}{l}\text { Screening of medical problems at unit } \\
\text { level should identify those unfit to deploy. } \\
\text { AEROMED to UK. }\end{array}$ \\
\hline 11 & $\begin{array}{l}\text { History of depression and deliberate } \\
\text { self-harm for } 1 \text { year prior to deployment. } \\
\text { Treatment stopped and upgraded } \\
\text { immediately prior to deployment. } \\
\text { Serious deliberate self-harm attempt. }\end{array}$ & P2 FE & $\begin{array}{l}\text { Decision to upgrade and immediately } \\
\text { post to potential conflict zone is } \\
\text { questionable. }\end{array}$ \\
\hline
\end{tabular}




\begin{tabular}{|c|c|c|c|}
\hline Serial & Clinical condition & $\begin{array}{l}\text { Deployed } \\
\text { Medical Grade }\end{array}$ & Actions and comments \\
\hline 12 & $\begin{array}{l}\text { Chronic groin pain following excision } \\
\text { of bone cyst and psoas release in last } \\
12 \text { months. Unable to perform duties. }\end{array}$ & P3 LE & $\begin{array}{l}\text { Inappropriate deployment. } \\
\text { AEROMED to UK. }\end{array}$ \\
\hline 13 & $\begin{array}{l}\text { Bilateral corns for many months. } \\
\text { Awaiting chiropody appointment. } \\
\text { Unable to wear boots. }\end{array}$ & P3 LE & $\begin{array}{l}\text { Inappropriate deployment. } \\
\text { AEROMED to UK. }\end{array}$ \\
\hline 14 & $\begin{array}{l}\text { Allergy to onions. Anaphylaxis x } 2 \text {. } \\
\text { Carries Epipen. }\end{array}$ & P2 FE & $\begin{array}{l}\text { Inappropriate grading and deployment. } \\
\text { Administrative return to unit. }\end{array}$ \\
\hline 15 & $\begin{array}{l}\text { Asthmatic taking regular becotide and } \\
\text { ventolin inhalers. Requiring ventolin } \\
\text { x10 per day in desert environment. }\end{array}$ & P2 FE & $\begin{array}{l}\text { Inappropriate grading and deployment. } \\
\text { AEROMED to UK. }\end{array}$ \\
\hline 16 & $\begin{array}{l}\text { Recurrent hypoglycaemia for } 1 \text { year } \\
\text { brought on by hot environments and } \\
\text { exertion. Under investigation at Frimley } \\
\text { Park Hospital and Manchester Royal } \\
\text { Infirmary. Hypoglycaemia while } \\
\text { exercising in NBC state R4. }\end{array}$ & P3 LE & $\begin{array}{l}\text { Inappropriate deployment. } \\
\text { AEROMED to UK. }\end{array}$ \\
\hline 17 & $\begin{array}{l}\text { Chronic bilateral foot pain. Seen by } \\
\text { consultant rheumatologist awaiting MRI } \\
\text { scan result \& follow up. Told downgraded } \\
\text { P3 L3 LE, but not on FMED } 965 \text {. }\end{array}$ & P2 FE & $\begin{array}{l}\text { Still deployed as otherwise "would } \\
\text { interfere with promotion prospects". } \\
\text { AEROMED to UK. }\end{array}$ \\
\hline 18 & $\begin{array}{l}\text { Six month history of haematuria, with } \\
\text { diagnosis of glomerulonephritis. Told } \\
\text { "not downgraded, but should not be } \\
\text { deployed". Recurrent frank haematuria. }\end{array}$ & P2 FE & $\begin{array}{l}\text { Inappropriate grading and deployment. } \\
\text { AEROMED to UK. }\end{array}$ \\
\hline 19 & $\begin{array}{l}2 \text { year history of cervical spondylosis } \\
\text { with paraesthesia of one arm; MRI } \\
\text { undertaken in UK and awaiting } \\
\text { orthopaedic opinion, but deployed. } \\
\text { Aggravated in theatre by carrying heavy } \\
\text { loads. }\end{array}$ & P2 FE & $\begin{array}{l}\text { Inappropriate grading and deployment } \\
\text { without specialist consultation. }\end{array}$ \\
\hline 20 & $\begin{array}{l}\text { 18-month history of 'gastritis' taking } \\
\text { ranitidine prescribed by MO on repeat } \\
\text { prescription. Asking for further drug. }\end{array}$ & P2 FE & $\begin{array}{l}\text { Given blind triple therapy by } \\
\text { gastroenterologist deployed with field } \\
\text { hospital, and 'outpatient' review in } \\
\text { theatre. }\end{array}$ \\
\hline 21 & $\begin{array}{l}\text { Soldier with chronic history of asthma. } \\
\text { Takes regular becotide and PRN ventolin. } \\
\text { Never downgraded. Presenting with } \\
\text { exacerbation of asthma. }\end{array}$ & P2 FE & $\begin{array}{l}\text { Inappropriate grading and deployment. } \\
\text { AEROMED to UK. }\end{array}$ \\
\hline 22 & $\begin{array}{l}\text { Severe balanitis for } 1 \text { week prior to } \\
\text { deployment. Seen on day of flight by } \\
\text { CMP in Germany and allowed to deploy. }\end{array}$ & P2 FE & $\begin{array}{l}\text { Inappropriate deployment with existing } \\
\text { condition. AEROMED to UK. }\end{array}$ \\
\hline 23 & $\begin{array}{l}\text { Wedge resection of great toenail, day } \\
\text { before deployment. Presented with } \\
\text { cellulitis. }\end{array}$ & P2 FE & $\begin{array}{l}\text { Inappropriate deployment with existing } \\
\text { condition. Admission for intravenous } \\
\text { antibiotics. }\end{array}$ \\
\hline 24 & $\begin{array}{l}\text { Fractured jaw wired in the UK. Wires } \\
\text { removed early for soldier to deploy. } \\
\text { Painful and mobile jaw every time puts } \\
\text { respirator on. }\end{array}$ & P2 FE & $\begin{array}{l}\text { Inappropriate clinical decision and } \\
\text { deployment. AEROMED to UK. }\end{array}$ \\
\hline 25 & $\begin{array}{l}\text { Painful varicocoele. Deployed } 5 \text { days } \\
\text { before outpatient appointment. Unable } \\
\text { to run and uncomfortable to walk. }\end{array}$ & P2 FE & $\begin{array}{l}\text { Inappropriate deployment with existing } \\
\text { condition. AEROMED to UK. }\end{array}$ \\
\hline 26 & $\begin{array}{l}\text { Young female soldier with history of } \\
\text { cervical intraepithelial neoplasia Grade } \\
\text { IV for } 1 \text { year, denied attendance at } \\
\text { outpatients by unit Sergeant Major prior } \\
\text { to deployment. Admitted with weight } \\
\text { loss and vomiting }\end{array}$ & P2 FE & $\begin{array}{l}\text { Inappropriate grading and deployment. } \\
\text { AEROMED to UK. }\end{array}$ \\
\hline
\end{tabular}




\begin{tabular}{|c|c|c|c|}
\hline Serial & Clinical condition & $\begin{array}{l}\text { Deployed } \\
\text { Medical Grade }\end{array}$ & Actions and comments \\
\hline 27 & $\begin{array}{l}\text { Right lateral meniscal tear. Confirmed } \\
\text { on MRI. Downgraded awaiting } \\
\text { outpatients ( } 3 \text { year history of symptoms } \\
\text { with delay in diagnosis). }\end{array}$ & P3 L3 LE & $\begin{array}{l}\text { Inappropriate deployment with existing } \\
\text { condition. } \\
\text { AEROMED to UK. }\end{array}$ \\
\hline 28 & $\begin{array}{l}\text { Asthmatic taking regular becotide and } \\
\text { ventolin. Downgraded for chronic knee } \\
\text { injury, but not for asthma. Pneumonia Jan } \\
\text { 03. Admitted with respiratory tract } \\
\text { infection. }\end{array}$ & P3 L3 LE & $\begin{array}{l}\text { Inappropriate deployment: requires } \\
\text { downgrading for asthma. } \\
\text { AEROMED to UK }\end{array}$ \\
\hline 29 & $\begin{array}{l}\text { Recent general anaesthetic for incision } \\
\& \text { drainage neck abscess in NHS hospital. } \\
\text { Deployed with wound packed and given } \\
\text { supply of Kaltostat dressings for daily } \\
\text { changes. }\end{array}$ & P2 FE & Admitted to $33 \mathrm{Fd}$ Hospital. \\
\hline 30 & $\begin{array}{l}\text { Fracture of dominant hand } 2 \text { nd } \\
\text { metacarpal } 1 \text { week prior to deployment. } \\
\text { Arrived in theatre with POP splint. }\end{array}$ & P2 FE & $\begin{array}{l}\text { Inappropriate deployment with } \\
\text { coexisting condition. } \\
\text { AEROMED to UK. }\end{array}$ \\
\hline 31 & $\begin{array}{l}\text { 52-year-old chronic asthmatic on } \\
\text { becotide and ventolin. Overwight. "Used } \\
\text { to drink heavily", but now } 50 \text { units per } \\
\text { week. Deaf (H3). Passed fit by MO at } \\
\text { Chilwell. No IPE to fit him.Unable to } \\
\text { keep up with troop. }\end{array}$ & P3 H2 H3 LE & AEROMED to UK. \\
\hline 32 & $\begin{array}{l}\text { Waiting for hip operation for } 3 \text { years } \\
\text { with planned date of } 14 \text { Mar } 03 \text {. }\end{array}$ & P2 FE & $\begin{array}{l}\text { Administrative return for operation by } 1 \\
\text { UK Div. }\end{array}$ \\
\hline 33 & $\begin{array}{l}\text { Downgraded P7. Believed had been } \\
\text { upgraded P2 after civilian consultation } \\
\text { in Germany. }\end{array}$ & P7 & $\begin{array}{l}\text { Administrative return to unit by } 1 \mathrm{UK} \\
\text { Div. }\end{array}$ \\
\hline 34 & $\begin{array}{l}\text { TA soldier with } 18 \text { month history of } \\
\text { depression, taking amitryptilene until } \\
\text { Nov } 02 \text {. Stopped medication himself. } \\
\text { Did not declare history. In theatre } 1 \\
\text { day before referred with depression and } \\
\text { intent to self harm. }\end{array}$ & P2 FE & $\begin{array}{l}\text { Inappropriate grading and deployment. } \\
\text { AEROMED to UK. }\end{array}$ \\
\hline 35 & $\begin{array}{l}\text { Chronic asthmatic on regular } \\
\text { beclomethasone, serevent and salbutamol } \\
\text { inhalers. Downgraded. Was concerned } \\
\text { about deploying with regards to impact } \\
\text { of NAPS on asthma. Required to double } \\
\text { own dose of steroid in theatre to control } \\
\text { symptoms. }\end{array}$ & P3 LE & $\begin{array}{l}\text { Inappropriate deployment. } \\
\text { AEROMED to UK. }\end{array}$ \\
\hline 36 & $\begin{array}{l}\text { Cough, SOB, chest pain and bloody } \\
\text { sputum for } 5 \text { days. Welder with history } \\
\text { of copper, manganese, zinc and } \\
\text { aluminium toxicity presenting as } \\
\text { pulmonary embolism } 2 \text { years previously. } \\
\text { Warned could suffer repeat episodes } \\
\text { related to same aetiology. } 3 \text { monthly } \\
\text { serum levels of heavy metals. }\end{array}$ & $\begin{array}{l}\text { P3 LE } \\
\text { (permanent) }\end{array}$ & $\begin{array}{l}\text { Questionable fitness to deploy. } \\
\text { AEROMED to UK. }\end{array}$ \\
\hline 37 & $\begin{array}{l}\text { Asthmatic taking seretide and ventolin } \\
\text { inhalers for } 2 \text { years. Not downgraded. } \\
\text { Presented with respiratory infection. }\end{array}$ & P2 FE & $\begin{array}{l}\text { Inappropriate grading and deployment. } \\
\text { AEROMED to UK. }\end{array}$ \\
\hline 38 & $\begin{array}{l}\text { Soldier with } 40 \% \text { renal function. } \\
\text { Downgraded by renal physician and told } \\
\text { could not deploy to hot environments. } \\
\text { Upgraded by general physician } \\
\text { immediately prior to deployment. } \\
\text { Presented with loin pain. }\end{array}$ & P2 FE & $\begin{array}{l}\text { Inappropriate grading and questionable } \\
\text { medical decision. } \\
\text { AEROMED to UK. }\end{array}$ \\
\hline
\end{tabular}




\begin{tabular}{|c|c|c|c|}
\hline Serial & Clinical condition & $\begin{array}{l}\text { Deployed } \\
\text { Medical Grade }\end{array}$ & Actions and comments \\
\hline 39 & $\begin{array}{l}4 \text { week history of back injury with } \\
\text { sciatica. Seen by RMO in UK. Not } \\
\text { investigated or downgraded. Presented } \\
\text { with sciatic nerve and saddle } \\
\text { distribution neurology. }\end{array}$ & P2 FE & $\begin{array}{l}\text { Inadequate medical management and } \\
\text { inappropriate grading. } \\
\text { AEROMED to UK. }\end{array}$ \\
\hline 40 & $\begin{array}{l}\text { TA soldier. Had splenectomy in } 2001 . \\
\text { Aware may preclude deployment. } \\
\text { Now worried about taking antimalarials. }\end{array}$ & P2 FE & $\begin{array}{l}\text { Inappropriate grading. Should not rely on } \\
\text { individual to declare own fitness to } \\
\text { deploy. AEROMED to UK. }\end{array}$ \\
\hline 41 & $\begin{array}{l}\text { 40-year-old soldier with } 1 \text { year history } \\
\text { of SVT; } 2 \text { x ablations awaiting 3rd but } \\
\text { missed appointment because of } \\
\text { deployment; "referred for regrading" but } \\
\text { currently P2FE; regular bisoprolol to } \\
\text { control symptoms; heart rate } 35 / \text { minute; } \\
\text { requesting repeat prescription. }\end{array}$ & P2 FE & $\begin{array}{l}\text { Inappropriate grading and deployment. } \\
\text { Physician's decision to retain in theatre. }\end{array}$ \\
\hline 42 & $\begin{array}{l}\text { Chronic facet joint back pain; wanting } \\
\text { to sign off; delayed from leaving army so } \\
\text { could deploy (unwillingly); constant back } \\
\text { pain aggravated in theatre; } 3 \text { out of } 6 \\
\text { weeks spent on light duties. }\end{array}$ & $\begin{array}{l}\text { P3 L3 LE } \\
\text { (permanent) }\end{array}$ & $\begin{array}{l}\text { Inappropriate deployment; poor man } \\
\text { management. AEROMED to UK. }\end{array}$ \\
\hline 43 & $\begin{array}{l}\text { Chronic asthmatic taking regular becotide } \\
\text { and ventolin. Increasing use of ventolin in } \\
\text { theatre: removing respirator in order to } \\
\text { use ventolin. }\end{array}$ & P2 FE & $\begin{array}{l}\text { Inappropriate grading and deployment. } \\
\text { AEROMED to UK. }\end{array}$ \\
\hline 44 & $\begin{array}{l}\text { Chronic tonsillitis. Light duties chit for } 5 \\
\text { days dated } 25 \mathrm{Feb} 03 \text { stating "unfit to } \\
\text { deploy". Not downgraded. Allowed to } \\
\text { deploy by SMO so long as "monitored } \\
\text { daily to see if can cope". In theatre } 2 \\
\text { weeks. Unable to swallow. } \\
\text { Tonsils opposed. }\end{array}$ & P2 FE & $\begin{array}{l}\text { Inappropriate grading and deployment. } \\
\text { Clinical decision poor to allow } \\
\text { deployment. AEROMED to UK. }\end{array}$ \\
\hline 45 & $\begin{array}{l}\text { L/Cpl, thyrotoxic } 6 / 12 \text { prior to } \\
\text { deployment. Treated and monitored with } \\
\text { thyroid function tests every } 6 \text { weeks; still } \\
\text { intermittently elevated. Last blood test } 2 \\
\text { weeks before deployment, with "results to } \\
\text { be sent to theatre". Unwell several days. } 1 \\
\text { mile into run tremor +++. Goitre. } \\
\text { P111/minute in A\&E. }\end{array}$ & P2 FE & $\begin{array}{l}\text { Inappropriate grading and } \\
\text { deployment. Lack of perception of } \\
\text { civilian practitioner regarding } \\
\text { employment. AEROMED to UK. }\end{array}$ \\
\hline 46 & $\begin{array}{l}\text { Chronic exercise induced asthma. Not } \\
\text { downgraded. Used } 2 x \text { ventolin inhalers } \\
\text { in } 5 \text { weeks. }\end{array}$ & P2 FE & $\begin{array}{l}\text { Inappropriate grading and deployment. } \\
\text { AEROMED to UK. }\end{array}$ \\
\hline 47 & $\begin{array}{l}\text { Chronic cold induced asthma. Not } \\
\text { downgraded. Increasing symptoms } \\
\text { ( } 7 \text { x 2-puffs in } 1 \text { day). }\end{array}$ & P2 FE & $\begin{array}{l}\text { Inappropriate grading and deployment. } \\
\text { AEROMED to UK. }\end{array}$ \\
\hline 48 & $\begin{array}{l}\text { Inguinal hernia diagnosed } 2 \text { months } \\
\text { before deployment. Deployed despite } \\
\text { persistent pain. Referred by RMO for } \\
\text { herniorrhaphy. }\end{array}$ & P2FE & $\begin{array}{l}\text { Inappropriate grading and deployment. } \\
\text { AEROMED to UK. }\end{array}$ \\
\hline 49 & $\begin{array}{l}\text { Fracture dislocation of left ring finger } 4 \\
\text { months before deployment. Swollen and } \\
\text { painful finger. Fusion operation cancelled. } \\
\text { Cannot lift. Unable to get into NBC } \\
\text { outer gloves. }\end{array}$ & P2 FE & $\begin{array}{l}\text { Inappropriate grading and deployment. } \\
\text { AEROMED to UK. }\end{array}$ \\
\hline 50 & $\begin{array}{l}\text { Permanently downgraded with asthma. } \\
\text { Requires salbutamol for symptoms after } \\
400 \mathrm{~m} \text { jog. Deployed with a unit expected } \\
\text { to spend } 48 \text { hours in NBC Dress State } \\
4 \text { Romeo. Unfit for role or deployment. }\end{array}$ & P3 LE & $\begin{array}{l}\text { Inappropriate deployment. } \\
\text { AEROMED to UK. }\end{array}$ \\
\hline
\end{tabular}




\section{Discussion}

Existing Downgrading Ignored. The grade of P3 LE recognises that the soldier's functional capacity is 'below average' and that their combatant capacity is 'restricted'; the grading allows deployment in the combat zone in any role which is not primarily a fighting one (LE, lines of communication everywhere) (1). The employment standard 'HO' (home only) limits the soldier's deployment to UK (+ Germany; and Nepal for Gurkhas) where suitable medical facilities can be guaranteed for the continuing management of their condition. In only one case, therefore, can it truly be said that an existing downgrading was ignored.

Inappropriate Medical Grading. What is apparent is that the grade of P3 LE correctly applied according to JSP 346 regulations may not afford the soldier the protection they need. In particular, patients with a history of chronic asthma taking regular prophylactic drugs (inhaled corticosteroids and/or long-acting $\beta_{2}$-agonists) who are deployed to the environment studied can expect to suffer an exacerbation of their symptoms. This may be multi-factorial through dust, reduced humidity, increased exercise, increased psychological stress, and a reduced ability to comply with regular medication. It is not a new observation: one of the two leading causes for aeromedical evacuation in the Gulf War 1991 (nontrauma cases) was asthma (2).

The employment standards "FT" (forward temperate) and "LT" (lines temperate) protect soldiers with conditions that are predictably worsened by extremes of temperature from deployment to extreme environments. A soldier who has unexplained recurrent hypoglycaemia precipitated by hot environments and exertion will predictably do poorly when sent to the desert to exercise in NBC Dress State 4-Romeo (case 16)! With a high prevalence of desert deployments for UK troops since 2000 (Exercise Saif Sareea II; Operation Jacana; Operation Telic) due consideration should be given to the use of these employment standards.

Soldiers under investigation through outpatients or awaiting an outpatient appointment require protection until a definitive diagnosis is made (example, serial 19): the responsibility and process of downgrading in this situation requires to be reinforced. When the clinician decides a soldier is unfit to deploy there is no protection unless the soldier is downgraded (example, serial 18): a verbal communication from the clinician will not be regarded as authority by the soldier's Warrant Officer. If a soldier is downgraded and this does not appear on FMED 965 (field version of primary care medical documentation, FMED 4) then there is a system failure (example, serial 17).
Misconception of Deployed Clinical

Capability. A field hospital has a haematology and biochemistry capability limited to support the diagnosis of common serious and life-threatening conditions. A poor understanding of this capability is revealed by the expectation of medical officers that the hospital can perform a wider range of tests. It is poor clinical judgement to refer to a field hospital for review when the confirmatory test is not available, or even when it is available if an abnormal result will necessarily require the patient to return to UK. Importantly, it perhaps represents a corporate failing of our process of professional development and military exercise if medical officers do not know the contents of the modules. However, drugs are not provided in an exercise environment (although they are the principal armamentarium of the general and emergency physician) and it is difficult to become familiar with something to which you are not exposed.

Treatment Incomplete. It is again an indicator of poor clinical judgement to deploy a soldier with an identified condition that is untreated or incompletely treated. Serial 6 had an untreated abscess; serial 48 had a symptomatic inguinal hernia; and there were two cases with Plaster of Paris in situ. It is routine for RAF Police to perform security checks on personnel embarking on military flights: this routine should include the active exclusion of any soldier attempting to fly to an operational area wearing a Plaster of Paris cast.

\section{Conclusions}

The subjective experience of Emergency Medicine deployed at Role 3 since OP AGRICOLA of soldiers deployed inappropriately with chronic conditions has been confirmed in this series of patients in OP TELIC. Review of the medical grading process is needed to protect those soldiers who are awaiting outpatient opinion or definitive diagnosis from investigation, and to provide an employability grading that matches a soldier's fitness for operational role. The use of medical grades that protect a soldier with an environmental-related condition from being deployed to a specific environment requires to be highlighted. Training is needed to ensure all clinicians are familiar with the Role 3 diagnostic and treatment capability.

\section{References}

1. Ministry of Defence 1992. JSP 346 PULHHEEMS, A Joint Service System of Medical Classification.

2. Hodgetts TJ, Ratcliffe G. Gulf Medical Audit - an analysis of medical casualties evacuated to the UK from the Gulf during Operation Granby. F R Army Med Corps 1992; 138: 9-13. 